\title{
SCIDOC
}

International Journal of Dentistry and Oral Science (IJDOS)

ISSN: 2377-8075

\section{Knowledge, Attitude And Practice Survey On Nonvital Bleaching Among Dentist}

Research Article

Aishuwariya. $\mathrm{T}^{1}$, Subash Sharma ${ }^{2^{*}}$

${ }^{1}$ Department of Conservative Dentistry and Endodontics, Saveetha Dental College and Hospitals, Saveetha Institute of Medical and Technical Sciences, Saveetha University, Chennai, India.

${ }^{2}$ Senior Lecturer, Department of Conservative Dentistry and Endodontics, Clinical Genetics Lab, Saveetha Dental College and Hospitals, Saveetha Institute of Medical and Technical Sciences, Saveetha University, Chennai - 600077, India.

\section{Abstract}

A cross-sectional KAP study was conducted using a questionnaire with closed questions among dentists of Chennai region. Information was collected regarding dental qualification, level of specialization. In addition, options regarding bleaching therapies including the first choice of material, technique and clinical practice for nonvital tooth bleaching therapies were included. A total number of 122 responses were received. In office bleaching therapy was broadly preferred $(92 \%)$ over at home $(8 \%)$ bleaching. For in office bleaching, the majority of the dentists answered to use Hydrogen peroxide followed by sodium perborate for nonvital therapies. In conclusion, the results of this study demonstrated that inoffice bleaching was broadly preferred over at home bleaching for nonvital teeth. The Hydrogen peroxide agents were preferred for nonvital tooth bleaching followed by sodium perborate.

Keywords: Non Vital Bleaching; Kap Survey; Sodium Hypochlorite; Hydrogen Peroxide.

\section{Introduction}

Patients often report to the dentist seeking treatment for their discoloured teeth to improve their appearance. There are two types of tooth discolorations as described in the literature: those caused by extrinsic factors and those caused by intrinsic congenital or systemic influence. The intensity of stains may be worsened if enamel defects coexist. Tooth discoloration presents two major challenges to a dentist. The first challenge is to ascertain the cause of the stain and the second is its management. Discoloration may be limited to a single tooth or several teeth in a single arch or it may be generalized and evident on all of the teeth. Main key for the treatment lies in recognition of actual cause for the discoloration. In some cases, scaling and polishing the teeth will improve the situation; however, more extensive treatment often is needed to achieve a satisfying result. Treatment options include vital and non-vital bleaching, micro abrasion, composite and porcelain veneers, and porcelain crowns. Sometimes combination of all these is preferred [1].
Bleaching treatments have become very popular with the increasing demand for aesthetics in practically all fields of everyday life. Vital tooth bleaching can be performed externally in vital teeth, using at-home or in-office techniques, or both techniques in combination. Nonvital bleaching for a root-filled tooth is carried out intracoronally or using a combination of external and internal procedures. Several products and different techniques are available for tooth bleaching, with most variations relating to concentration and type of peroxide releasing agents. Basically, the mechanism of action of bleaching agents is similar. Peroxide-containing agents break down into water and oxygen, which diffuses through the dental structure, causing oxidation and reduction of organic pigments that are located mainly within the dentin structure, ultimately producing the whitening effect [2]. While nonvital tooth bleaching is performed at the dental office using strong peroxide agents, such as high concentration hydrogen peroxide (HP) or hydrogen peroxide-releasing agents (carbamide peroxide - CP and sodium perborate - SP), vital tooth bleaching can be performed with high concentration (in-office) or low However, Bleaching treatments have become very popular with the increas-

\section{*Corresponding Author:}

Subash Sharma,

Senior Lecturer, Department of Conservative Dentistry and Endodontics, Clinical Genetics Lab, Saveetha Dental College and Hospitals, Saveetha Institute of Medical and Technical

Sciences, Saveetha University, Chennai - 600077, India.

Tel: 9840136543

E-mail: subash@saveetha.com

Received: May 04, 2021

Accepted: July 29, 2021

Published: August 02, 2021

Citation: Aishuwariya. T, Subash Sharma. Knowledge, Attitude And Practice Survey On Nonvital Bleaching Among Dentist. Int J Dentistry Oral Sci. 2021;8(8):3592-3595. doi: http://dx.doi.org/10.19070/2377-8075-21000735

Copyright: Subash Sharma 2021 . This is an open-access article distributed under the terms of the Creative Commons Attribution License, which permits unrestricted use, distribution and reproduction in any medium, provided the original author and source are credited. 
ing demand for esthetics. Vital tooth bleaching can be performed externally in vital teeth, using at-home or in-office techniques, or both techniques in combination. Nonvital bleaching for a rootfilled tooth is carried out intracoronally or using a combination of external and internal procedures [3]. Several products and different techniques are available for tooth bleaching. But, the mechanism of action of bleaching agents is similar. Peroxide-containing agents break down into water and oxygen, which diffuses through the dental structure, causing oxidation and reduction of organic pigments that are located mainly within the dentin structure, ultimately producing the whitening effect [4].

Nonvital tooth bleaching is performed at the dental office using strong peroxide agents, such as high concentration hydrogen peroxide or peroxide-releasing agents like carbamide peroxide and sodium perborate. Agent concentration and technique have been claimed to influence the bleaching outcome [5]. Some adverse effects have also been reported like in nonvital bleaching, the occurrence of external root resorption, morphological alterations in dental tissues, alteration of dental materials properties and decrease of tooth resistance $[6,7]$.

Previously our team has a rich experience in working on various research projects across multiple disciplines [8-22] Now the growing trend in this area motivated us to pursue this project.

So, this questionnaire-based survey was aimed to assess the preferred techniques and products to perform nonvital by a population of dentists from Chennai region. It was also investigated whether their options could be influenced by their time in clinical practice and the level of specialization.

\section{Materials And Method}

A structured questionnaire consisting of questions based on knowledge, attitude and clinical practice was distributed among the general dental practitioners through means of electronic media and other means of communication such as personal emails etc. The questionnaire held a total of 17 questions in which 10 were knowledge based, 7 questions to check the attitude of the practitioners and the clinical practice followed by them. The questionnaires were distributed randomly to practitioners. The responses were collected. The survey data was then collected together and analysed.

\section{Result And Discussion}

A total number of 122 responses were received. In office bleaching therapy was broadly preferred $(92 \%)$ over at home $(8 \%)$ bleaching. For in office bleaching, the majority of the dentists answered to use Hydrogen peroxide followed by sodium perborate for nonvital therapies.

Different options are available for the treatment of discoloured root canal treated teeth [23]. The bleaching has many advantages over the conventional options. For a tooth that has discoloured following devitalization, bleaching is preferred over full veneer crown especially when the tooth crown is intact [24].

Few studies suggested that it is the bulk of the remaining tooth structure rather than the dowel that provides strength and resist- ance to fracture of the endodontically treated tooth [25]. Also, Sorenson et al in their study had reported that there is no significant difference in the success rate achieved between anterior non-vital teeth with and without crowns. Thus, supporting the fact that endodontically treated anterior teeth does not require crown $[26,27]$.

This study showed that in-office bleaching is preferred over at home bleaching by the majority of the dentist. This can be due to the fact that dentists are more confident in performing bleaching procedures in their professional clinical practice [28]. However, some studies have mentioned that dentists prefer doing at-home therapies. [29-32].

For nonvital tooth bleaching, the first selected agent was Hydrogen peroxide $(70 \%)$. This can be attributed to the fact that this bleaching agent has been available to treat nonvitaldiscoloured teeth for more than 60 years [3]. Moreover, bleaching with Hydrogen Peroxide agents has provided good clinical results [33] in spite of their side effects like external root resorption because of the penetration of bleaching agents into the dentinal tubules at the cementoenamel junction, producing an immunological response in the periodontal tissues [6].

External cervical resorption is an inflammation mediated external resorption of the root, which is the most common complication following non-vital bleaching [34]. The underlying mechanism for this effect is unknown, but it is assumed that the bleaching agent reaches the periodontal tissue through the dentinal tubules and initiates an inflammatory reaction. It has also been speculated that the peroxide, by diffusing through the dentinal tubules, denatures the dentin, which then becomes an immunologically different tissue and is attacked as a foreign body [35]. So, in order to prevent this one should place an effective barrier to prevent the passage of peroxide into the periodontal space.

Carbamide peroxide is commonly used for at-home treatment modalities. This possible link between at home therapies and carbamide peroxide might have deteriorated the usage of both. The authors also observed that with the increase in clinical experience, the probability of suggesting in-office therapies was higher. This could probably suggest the important role played by clinical experience in decision-making. Use of at-home office therapies has been shown to produce an increase in the superficial porosity of enamel after treatment with 10\% Carbamide peroxide for 12 hours of daily application over four weeks. [36] Another study evaluated the effects of $10 \%$ PC used in an at-home whitening technique on dental enamel surface microhardness and found that the bleaching agent produced enamel surface modifications demonstrated by the decrease of microhardness values that started during the first week of CP application. Injury to the enamel surface was intensified after 14 days of treatment. McCraken and Haywood showed that the calcium loss after eight hours of at home bleaching corresponds to the erosion caused by cola-based soda applied for 2.5 minutes. [37]

Our institution is passionate about high quality evidence based research and has excelled in various fields [12, 38-47].

\section{Conclusion}

In conclusion, the results of this study demonstrated that in of- 
Table 1. This table shows the responses received from 122 dentists.

\begin{tabular}{|c|c|c|}
\hline Questions & Options & Percentage \\
\hline \multirow{3}{*}{ 1) Educational qualification } & BDS & \\
\hline & MDS-Endodontist & 62.3 \\
\hline & MDS-Other speciality & 33 \\
\hline \multirow{4}{*}{ 2) Extrinsic causes of tooth discoloration include all except } & Wine & 51.6 \\
\hline & Tea & \\
\hline & Tetracycline & 34 \\
\hline & Mouth rinse & 8.7 \\
\hline \multirow{4}{*}{ 3) Intrinsic causes of tooth discolouration include all except } & Endodontic materials & 53.2 \\
\hline & Aging & \\
\hline & Chromogens & 35.5 \\
\hline & Tetracycline & \\
\hline \multirow{4}{*}{ 4) Extrinsic stains are due to } & Hydration forces & \\
\hline & Hydrophobic interations & 28.5 \\
\hline & Dipole-Dipole & \\
\hline & All of the above & 63.4 \\
\hline \multirow{4}{*}{ 5) The most effective and commonly used method to remove extrinsic stains is } & Abrasives & \\
\hline & Surface active agents & \\
\hline & $\begin{array}{c}\text { Combination of abrasives and } \\
\text { Surface-active agents }\end{array}$ & \\
\hline & Bleaching agents & \\
\hline \multirow{4}{*}{ 6) The bleaching agents most commonly used for root filled teeth } & Hydrogen peroxide & \\
\hline & Carbamide peroxide & \\
\hline & Sodium perborate & \\
\hline & All of the above & 86.4 \\
\hline \multirow{4}{*}{ 7) What is the other name of at home non-vital bleaching technique } & Walking bleach technique & 88.6 \\
\hline & $\begin{array}{l}\text { Dentist prescribed bleaching } \\
\text { technique }\end{array}$ & \\
\hline & Thermocatalytic bleaching & \\
\hline & None of them & \\
\hline \multirow{3}{*}{$\begin{array}{l}\text { 8) What is the thickness of the cervical barrier before initiating a non vital } \\
\text { bleaching process? }\end{array}$} & Less than $3 \mathrm{~mm}$ & \\
\hline & $3 \mathrm{~mm}$ & 63.9 \\
\hline & More than $3 \mathrm{~mm}$ & 29.5 \\
\hline \multirow{5}{*}{ 9) How do you manage discoloured teeth in your practice? } & Abrasion & 1 \\
\hline & Bleaching & 79 \\
\hline & Crowns & 41 \\
\hline & Veneer & 8 \\
\hline & Over the counter bleaching agents & 1 \\
\hline \multirow{3}{*}{ 10) How do you manage non-vital teeth with discoloration } & Rct followed by crown & 41 \\
\hline & Rctfollowd by Veneer & 8 \\
\hline & Rct followed by bleaching & 74 \\
\hline \multirow{3}{*}{ 11) How do you perform non vital bleaching for treating disclored teeth? } & Yes & 8.3 \\
\hline & No & 9 \\
\hline & Sometimes & 85.8 \\
\hline \multirow{2}{*}{ 12) Are you aware about the various methods of non vital bleaching? } & Yes & 70 \\
\hline & No & 30 \\
\hline \multirow{2}{*}{ 13) If yes, which is your preferred treatment option } & In office & 92.5 \\
\hline & At home & 8 \\
\hline \multirow{3}{*}{ 14) Which among the following you use in your practice for non-vital bleaching } & Hydrogen peroxide & 61 \\
\hline & Sodium perborate & 10 \\
\hline & Carbamide peroxide & 32 \\
\hline \multirow{3}{*}{$\begin{array}{l}\text { 15) Have you come across any complication after performing non vital bleach- } \\
\text { ing? }\end{array}$} & Yes & 58 \\
\hline & No & 10 \\
\hline & Sometimes & 33 \\
\hline \multirow{3}{*}{$\begin{array}{l}\text { 16) Which is the most common complication you have seen in your practice } \\
\text { following non vital bleaching? }\end{array}$} & External root resorption & 37.5 \\
\hline & Chemical burn & 61.7 \\
\hline & Other & 4.2 \\
\hline \multirow{3}{*}{ 17) Do you follow up your cases after performing non vital bleaching and how? } & $\begin{array}{l}\text { Clinical examination and Radio- } \\
\text { graphs }\end{array}$ & 59.8 \\
\hline & Clinical examination & 12.3 \\
\hline & No Follow up & 27.9 \\
\hline
\end{tabular}

fice bleaching was broadly preferred over at home bleaching for nonvital teeth. The Hydrogen peroxide agents were preferred for nonvital tooth bleaching followed by sodium perborate.

\section{Acknowledgement}

With Sincere gratitude, we acknowledge the staff members of the department of Conservative Dentistry and Endodontics, Saveetha Dental College and study participants for their extended support towards the completion of research.

\section{References}

[1]. Setien VJ, Roshan S, Nelson PW. Clinical management of discolored teeth. General dentistry. 2008 May;56(3):294-304.

2]. Demarco FF, Meireles SS, Masotti AS. Over-the-counter whitening agents: a concise review. Braz Oral Res. 2009;23Suppl 1:64-70.Pubmed PMID: 19838560.

[3]. Joiner A. The bleaching of teeth: a review of the literature. J Dent. 2006 Aug 


\section{$1 ; 34(7): 412-9$}

[4]. Meireles SS, Fontes ST, Coimbra LA, Bona ÁD, Demarco FF. Effectiveness of different carbamide peroxide concentrations used for tooth bleaching: an in vitro study. J Appl Oral Sci. 2012;20:186-91.

[5]. Meireles SS, Heckmann SS, Leida FL, Santos IS, Bona Á, Demarco FF. Efficacy and safety of $10 \%$ and $16 \%$ carbamide peroxide tooth-whitening gels: a randomized clinical trial. Oper Dent. 2008 Nov;33(6):606-12.

[6]. Demarco FF, Freitas JM, Silva MP, Justino LM. Microleakage in endodontically treated teeth: influence of calcium hydroxide dressing following bleaching. IntEndod J. 2001 Oct;34(7):495-500.

[7]. Vieira C, Silva-Sousa YT, Pessarello NM, Rached-Junior FA, Souza-Gabriel AE. Effect of high-concentrated bleaching agents on the bond strength at dentin/resin interface and flexural strength of dentin. Braz Dent J. 2012;23(1):28-35.Pubmed PMID: 22460311.

[8]. Govindaraju L, Gurunathan D. Effectiveness of Chewable Tooth Brush in Children-A Prospective Clinical Study. J ClinDiagn Res. 2017 Mar;11(3):ZC31-ZC34.Pubmed PMID: 28511505.

[9]. Christabel A, Anantanarayanan P, Subash P, Soh CL, Ramanathan M, Muthusekhar MR, et al. Comparison of pterygomaxillarydysjunction with tuberosity separation in isolated Le Fort I osteotomies: a prospective, multi-centre, triple-blind, randomized controlled trial. Int J Oral Maxillofac Surg. 2016 Feb 1;45(2):180-5

[10]. Soh CL, Narayanan V. Quality of life assessment in patients with dentofacial deformity undergoing orthognathic surgery--a systematic review. Int J Oral Maxillofac Surg. 2013 Aug;42(8):974-80.Pubmed PMID: 23702370.

[11]. Mehta M, Deeksha, Tewari D, Gupta G, Awasthi R, Singh H, et al. Oligonucleotide therapy: An emerging focus area for drug delivery in chronic inflammatory respiratory diseases. ChemBiol Interact. 2019 Aug 1;308:206215.Pubmed PMID: 31136735

[12]. Ezhilarasan D, Apoorva VS, Ashok Vardhan N. Syzygiumcumini extract induced reactive oxygen species-mediated apoptosis in human oral squamous carcinoma cells. J Oral Pathol Med. 2019 Feb;48(2):115-121.Pubmed PMID: 30451321

[13]. Campeau PM, Kasperaviciute D, Lu JT, Burrage LC, Kim C, Hori M, et al. The genetic basis of DOORS syndrome: an exome-sequencing study. Lancet Neurol. 2014 Jan;13(1):44-58.Pubmed PMID: 24291220.

[14]. Sneha S. Knowledge and awareness regarding antibiotic prophylaxis for infective endocarditis among undergraduate dental students. Asian J Pharm Clin Res. 2016 Oct 1:154-9.

[15]. Christabel SL, Linda Christabel S. Prevalence of type of frenal attachment and morphology of frenum in children, Chennai, Tamil Nadu. World J. Dent. 2015 Oct;6(4):203-7

[16]. Kumar S, Rahman R. Knowledge, awareness, and practices regarding biomedical waste management among undergraduate dental students. Asian J Pharm Clin Res. 2017;10(8):341.

[17]. Sridharan G, Ramani P, Patankar S. Serum metabolomics in oral leukoplakia and oral squamous cell carcinoma. J Cancer Res Ther. 2017 Jul 1;13(3):556561

[18]. Ramesh A, Varghese SS, Doraiswamy JN, Malaiappan S. Herbs as an antioxidant arsenal for periodontal diseases. J IntercultEthnopharmacol. 2016 Jan 27;5(1):92-6.Pubmed PMID: 27069730.

[19]. Thamaraiselvan M, Elavarasu S, Thangakumaran S, Gadagi JS, Arthie T. Comparative clinical evaluation of coronally advanced flap with or without platelet rich fibrin membrane in the treatment of isolated gingival recession. J Indian SocPeriodontol. 2015 Jan;19(1):66-71.

[20]. Thangaraj SV, Shyamsundar V, Krishnamurthy A, Ramani P, Ganesan K, Muthuswami M, et al. Molecular Portrait of Oral Tongue Squamous Cell Carcinoma Shown by Integrative Meta-Analysis of Expression Profiles with Validations. PLoS One. 2016 Jun 9;11(6):e0156582.Pubmed PMID: 27280700.

[21]. Ponnulakshmi R, Shyamaladevi B, Vijayalakshmi P, Selvaraj J. In silico and in vivo analysis to identify the antidiabetic activity of beta sitosterol in adipose tissue of high fat diet and sucrose induced type- 2 diabetic experimental rats. ToxicolMech Methods. 2019 May;29(4):276-290.Pubmed PMID: 30461321.

[22]. Ramakrishnan M, Shukri M. Fluoride, Fluoridated Toothpaste Efficacy And Its Safety In Children-Review. Int J Pharm Res. 2018 Oct 1;10(04):109-14.

[23]. Leith R, Moore A, O'Connell AC. An effective bleaching technique for non-vital, discoloured teeth in children and adolescents. J Ir Dent Assoc 55:184-189.

[24]. Standlee JP, Caputo AA, Hanson EC. Retention of endodontic dowels: effects of cement, dowel length, diameter, and design. J Prosthet Dent. 1978 Apr 1;39(4):400-5
[25]. Trabert KC, Caputo AA, Abou-Rass M. Tooth fracturel3-A comparison of endodontic and restorative treatments. J Endod. 1978 Nov 1;4(11):341-5.

[26]. Sorensen JA, Martinoff JT. Clinically significant factors in dowel design. J Prosthet Dent. 1984 Jul 1;52(1):28-35.

[27]. Goerig AC, Mueninghoff LA. Management of the endodontically treated tooth. Part I: Concept for restorative designs. J Prosthet Dent. 1983 Mar $1 ; 49(3): 340-5$

[28]. Hatherell S, Lynch CD, Burke FM, Ericson D, Gilmour AS. Attitudes of final-year dental students to bleaching of vital and non-vital teeth in Cardiff, Cork, and Malmö. J Oral Rehabil. 2011 Apr;38(4):263-9.Pubmed PMID: 20819136.

[29]. Auschill TM, Hellwig E, Schmidale S, Sculean A, Arweiler NB. Efficacy, side-effects and patients' acceptance of different bleaching techniques (OTC, in-office, at-home). Oper Dent. 2005 Mar 1;12:88.

[30]. Demarco FF, Conde MC, Ely C, Torre EN, Costa JR, Fernández MR, et al. Preferences on vital and nonvital tooth bleaching: a survey among dentists from a city of southern Brazil. Braz Dent J. 2013 Sep-Oct;24(5):527-31. Pubmed PMID: 24474298.

[31]. Brunton PA, Burke FJ, Sharif MO, Creanor S, Hosey MT, Mannocci F, et al. Contemporary dental practice in the UK in 2008: aspects of direct restorations, endodontics and bleaching. Br Dent J. 2012 Jan 27;212(2):63-7. Pubmed PMID: 22281627.

[32]. Deliperi S, Bardwell DN, Papathanasiou A. Clinical evaluation of a combined in-office and take-home bleaching system. J Am Dent Assoc. 2004 May 1;135(5):628-34.

[33]. Glockner K, Hulla H, Ebeleseder K, Städtler P. Five-year follow-up of internal bleaching. Braz Dent J. 1999;10(2):105-10.Pubmed PMID: 10863397.

[34]. Friedman S, Rotstein I, Libfeld H, Stabholz A, Heling I. Incidence of external root resorption and esthetic results in 58 bleached pulpless teeth. Endod Dent Traumatol. 1988 Feb;4(1):23-6.Pubmed PMID: 3268415.

[35]. Lado EA, Stanley HR, Weisman MI. Cervical resorption in bleached teeth. Oral Surg Oral Med Oral Pathol. 1983 Jan 1;55(1):78-80.

[36]. Pinto CF, Leme AF, Cavalli V, Giannini M. Effect of $10 \%$ carbamide peroxide bleaching on sound and artificial enamel carious lesions. Braz. Dent. J. 2009;20:48-53.

[37]. McCracken MS, Haywood VB. Demineralization effects of 10 percent carbamide peroxide. J Dent. 1996 Nov 1;24(6):395-8.

[38]. VijayashreePriyadharsini J. In silico validation of the non-antibiotic drugs acetaminophen and ibuprofen as antibacterial agents against red complex pathogens. J Periodontol. 2019 Dec;90(12):1441-1448.Pubmed PMID: 31257588.

[39]. Pc J, Marimuthu T, Devadoss P, Kumar SM. Prevalence and measurement of anterior loop of the mandibular canal using CBCT: A cross sectional study. Clin. Implant Dent. Relat. Res. 2018 Apr 6;20(4):531-4.

[40]. Ramesh A, Varghese S, Jayakumar ND, Malaiappan S. Comparative estimation of sulfiredoxin levels between chronic periodontitis and healthy patients - A case-control study. J Periodontol. 2018 Oct;89(10):1241-1248.Pubmed PMID: 30044495

[41]. Ramadurai N, Gurunathan D, Samuel AV, Subramanian E, Rodrigues SJ. Effectiveness of $2 \%$ Articaine as an anesthetic agent in children: randomized controlled trial. Clin. Oral Investig. 2019 Sep;23(9):3543-50.

[42]. Sridharan G, Ramani P, Patankar S, Vijayaraghavan R. Evaluation of salivary metabolomics in oral leukoplakia and oral squamous cell carcinoma. J Oral Pathol Med. 2019 Apr;48(4):299-306.

[43]. Mathew MG, Samuel SR, Soni AJ, Roopa KB. Evaluation of adhesion of Streptococcus mutans, plaque accumulation on zirconia and stainless steel crowns, and surrounding gingival inflammation in primary molars: randomized controlled trial. Clin Oral Investig. 2020 Sep;24(9):1-6.Pubmed PMID: 31955271

[44]. Samuel SR. Can 5-year-olds sensibly self-report the impact of developmental enamel defects on their quality of life? Int J Paediatr Dent. 2021 Mar;31(2):285-286.Pubmed PMID: 32416620.

[45]. R H, Ramani P, Ramanathan A, R JM, S G, Ramasubramanian A, et al. CYP2 C9 polymorphism among patients with oral squamous cell carcinoma and its role in altering the metabolism of benzo[a]pyrene. Oral Surg Oral Med Oral Pathol Oral Radiol. 2020 Sep;130(3):306-312.Pubmed PMID: 32773350.

[46]. Chandrasekar R, Chandrasekhar S, Sundari KKS, Ravi P. Development and validation of a formula for objective assessment of cervical vertebral bone age. ProgOrthod. 2020 Oct 12;21(1):38.Pubmed PMID: 33043408.

[47]. Priyadharsini JV, Girija AS, Paramasivam A. In silico analysis of virulence genes in an emerging dental pathogen A. baumannii and related species. Arch Oral Biol. 2018 Oct 1;94:93-8. 